\title{
Recognition versus Disclosure: An Investigation of the Impact on Equity Risk Using UK Operating Lease Disclosures
}

\author{
Vivien Beattie, Alan Goodagre and Sarah Thomson*
}

\section{INTRODUCTION}

In recent years, the debate surrounding the impact of recognition versus disclosure has assumed increasing significance in many countries. This is largely due to the growing importance of intangible, difficult to measure, assets. 'Recognition' is defined as 'the process of íncorporating an item into the financial statements', while 'disclosure' refers to 'information about the items in financial statements and their measures that may be provided by notes' (FASB, 1984). In the US and UK, for example, many recent accounting standards include disclosure requirements and some comprise only disclosure requirements (e.g., financial instruments). The sheer volume of disclosures found in modern financial reports has resulted in concern being expressed that disclosure overload is occurring, whereby critical disclosure information is being obscured (Johnson, 1992). FASB (1984) has stated that generally the most useful information about elements and their measurement should be recognised and that disclosure is not a substitute for recognition. ${ }^{1}$

\footnotetext{
* The authors are respectively, Professor, Senior Lecturer and PhD research student at the University of Stirling. The financial support of the Carnegie Educational Trust (for Sarah Thomson) is gratefully acknowledged. The authors also wish to thank the anonymous referee, Dennis Oswald, the journal editors and participants at the Capital Markets Conference 2000 for their extremely helpful comments on an earlier draft of this paper.

Address for correspondence: Alan Goodacre, Department of Accounting, Finance and Law, University of Stirling, Stirling FK9 4LA, UK.

e-mail: Alan.Goodacre@stir.ac.uk
} 
In contrast to this view, market efficiency (the maintained hypothesis of most academic empirical research in financial reporting) assumes an equivalence between recognition and disclosure, i.e., the market accurately processes information irrespective of its location within the financial report. However, empirical studies do not provide strong support for the equivalence argument. These studies are of two principal types. First, there is a series of market-based studies that investigates whether market equity risk assessments incorporate off-balance sheet disclosures and whether these assessments are differentially affected by disclosure versus recognition (Bowman, 1980a; Dhaliwal, 1986; Imhoff, Lipe and Wright, 1993; Ely, 1995a; and Gallery and Imhoff, 1998). ${ }^{2}$ The main accounting issues that have provided the basis for such research are unfunded pension obligations and leases. In the US setting, studies have found that lease footnote disclosures are associated with market assessments of equity risk (Bowman, 1980a; Imhoff et al., 1993; and Ely, 1995a), although there is no clear evidence regarding the method of evaluation used. However, an Australian study failed to find market corrections for off-balance sheet operating lease disclosures (Gallery and Imhoff, 1998).

Second, there have also been experimental and survey studies that examine the impact of recognition versus disclosure on individual financial statement users (e.g., Harper, Mister and Strawser, 1987 and 1991; Wilkins and Zimmer, 1983a and 1983b; Wilkins, 1984; Munter and Ratcliffe, 1983; and Gopalakrishnan and Parkash, 1996). These studies, the majority of which have been conducted in a US setting, also provide little support for the equivalence of recognition and disclosure. ${ }^{3}$

A further motivation for this study is that, in 1996, standardsetters in the UK, US, Canada, Australia and New Zealand, together with the IASC, published a discussion paper, Accounting for Leases: A New Approach, which proposes that all leases be capitalised (McGregor, 1996). The ASB issued a discussion paper along these lines in late 1999 (ASB, 1999). Thus, by investigating whether the UK market incorporates operating lease obligations in its assessment of equity risk, this study provides policy-relevant, ex ante research in support of the standard-setting process (the paucity of research of this type was lamented by Schipper, 1994). Moreover, it also answers the call 
for research into aspects of the recognition versus disclosure debate made by Johnson (1992).

The current study contributes to the ongoing recognition versus disclosure debate by investigating the relationship between operating lease disclosures and equity risk assessments made by the capital market in the UK. Under SSAP 21 (ASC, 1984), an operating lease is one which is not classified as a finance lease, the latter being defined as one which transfers substantially all the risks and rewards of ownership to the lessee. ${ }^{4}$ Following previous market-based studies, the approach adopted is to conduct an indirect test to determine whether there is an association between equity risk and an operating lease adjustment to financial risk. ${ }^{5}$ This test will provide evidence as to whether investors/analysts view operating leases from a property rights perspective or from an ownership perspective. ${ }^{6}$ Two alternative operating lease evaluation methods are considered in order to establish which method, if either, appears to be employed by UK investors/analysts. The first method is a sophisticated present value method based upon a constructive capitalisation procedure. The second method is a simple factor (multiplier) method.

The UK is particularly valuable as the setting for this study for three reasons. First, operating leases represent a significant (and growing) financial obligation for many companies. By 1994, leasing represented $15.8 \%$ of the total investment in equipment (Finance and Leasing Association, 1994); this had risen to $19 \%$ by 1997 (Tolley's, 1998). Recent research has shown that, among listed companies in 1994, the annual operating lease liability was approximately 13 times that of finance leases (Beattie, Goodacre and Thomson, 2000). Moreover, for a sample of 232 such companies in 1994, the unrecorded long-term liability was estimated to represent $39 \%$ of reported long-term debt, recognition of which would increase gearing (defined as net debt to equity) by $260 \%$ (Beattie, Edwards and Goodacre, 1998). ${ }^{7}$ The magnitude of operating leasing activity in the UK allows a powerful test of the basic relationship between disclosures and equity risk assessment to be conducted.

Second, the precise content of the operating lease disclosures made in the UK differ from those in the US. In the US, companies are required to disclose total minimum future 
payments with remaining terms of more than one year (reported separately for each of the next five years and combined thereafter). In the UK, companies are required to disclose next year's minimum payments, analysed according to the period in which the annual commitment expires (next year; within the second to fifth years inclusive; and over five years from the balance sheet date). This is further analysed between land and buildings and other asset categories. Thus, the UK disclosures are, in some respects, more informative than those in the US. This permits the two alternative methods of lease evaluation to be discriminated more clearly.

Third, we are aware of no evidence in the UK capital markets literature regarding the impact of footnote disclosures on company valuation (conducted from either a risk or return perspective). Moreover, there is little published evidence on the methods used by market participants to adjust for off-balance sheet financing. There are tentative suggestions (Day, 1986) that 'off-balance sheet' financing is of interest to UK investment analysts, yet company accounts are not seen as containing any price sensitive information. There is also evidence to suggest that UK investors/analysts may be less sophisticated than their US counterparts (Arnold, Moizer and Noreen, 1984, p.15; and Anderson and Epstein, 1996, p.165)., More specifically, UK investors/analysts have been found to make less use of financial ratios, on which operating lease capitalisation could have a significant impact. Breton and Taffler (1995) conducted a laboratory experiment using investment analysts to investigate their response to nine forms of creative accounting, one of which was non-capitalised leases. They found that, in general, subjects did not make adjustments when calculating familiar financial ratios. ${ }^{10}$

The present study makes the following contributions to knowledge. First, the investigation of the capital market impact of lease accounting disclosures across additional environmental settings can be expected to provide further evidence regarding the nature of this relationship that will contribute to the general recognition versus disclosure debate. Second, the setting supports a more powerful test of the specific association between market equity risk assessment and operating lease disclosures than has previously been conducted, which may assist in resolving the conflicting evidence in extant evidence. Third, the present 
study investigates more thoroughly the robustness of the results to different proxies for operating/asset risk. Finally, policyrelevant, ex ante research in support of the standard setting process is provided.

The remainder of the paper is structured as follows: The next section discusses previous related research and Section 3 describes the research methods employed in this study. Section 4 describes the data used. Results are reported in Section 5, while Section 6 offers a summary and conclusions.

\section{PREVIOUS RESEARCH}

In this section, we first discuss briefly the nature of equity risk. Thereafter, previous market-based studies related specifically to market equity risk assessments are reviewed.

\section{(i) Equity Risk}

The return from an equity investment is sensitive to unanticipated events. The degree of sensitivity, defined as equity risk, arises from the nature of a firm's assets and operating activities (business risk) and its financial policy or capital structure (financial risk). Elements of both business risk and financial risk affect the majority of equities to some degree. For example, most returns are at risk from an increase in inflation. In this situation, business risk and financial risk constitute systematic or market risk. However, some elements of business or financial risk affect only a small number of equities. For example, industrial action by a firm's workforce would only influence its own returns and possibly the returns of its primary suppliers/competitors. When only a small number of equities are affected, business and financial risk constitute unsystematic or specific risk. Both systematic risk and unsystematic risk are reflected in variations in company returns over time, thus providing a total equity risk measure.

\section{(ii) Market-Based Studies of Equity Risk}

Several US empirical studies have modelled equity risk as a function of business (operating/asset) risk and financial risk 
(e.g., Beaver, Kettler and Scholes, 1970; Hamada, 1972; Bowman, 1980a and 1980b; and Dhaliwal, 1986). Business (operating/ asset) risk has been proxied by accounting beta, the covariability of a firm's earnings with the accounting earnings of the market portfolio (Bowman, 1980a; and Dhaliwal, 1986). As an alternative/extension to this proxy, industry dummy variables have been introduced (Bowman, 1980a; Imhoff et al., 1993; and Narayanaswamy, 1994) ${ }^{11}$ to control for operating/asset risk differences across firms. Financial risk has been proxied by financial leverage, which has been found to have a significant relationship with equity risk.

Previous studies that model the determinants of equity risk have focused either on total equity risk (standard deviation of returns) or systematic/market risk (beta). Those considering systematic risk take the view that investors need face only the risk related to market movements, since firm-specific risk can be eliminated through holding a diversified portfolio. However, others suggest that total equity risk is more consistent with accounting measures of risk, such as financial leverage, because accounting measures of risk reflect both systematic and individualistic risk components (Beaver et al., 1970).

The majority of previous studies have considered the relationship between equity risk and leverage ratios determined simply from reported balance sheet figures (Beaver et al., 1970; and Hamada, 1972). Less evidence exists concerning situations that impact upon leverage ratios but where the relevant information is disclosed outside the balance sheet. Five studies have been identified (four conducted in the US market setting and one in Australia) that examine the value-relevance of disclosures outside the balance sheet. Table 1 summarises the proxies used to represent equity risk, business (operating/asset) risk and financial risk, to highlight the essential differences between these studies. Bowman (1980a) and Dhaliwal (1986) focus on market/systematic risk, while Imhoff et al. (1993), Ely (1995a) and Gallery and Imhoff (1998) focus on total equity risk. The findings of each study are now considered.

Bowman (1980a) examined the relationship between market (systematic) risk and the present value of finance leases reported to the SEC under $A S R-147$ prior to $S F A S 13$ requiring finance lease capitalisation. He found finance leases to make a significant 
Table 1

Prior Market-based Research of Disclosure versus Recognition

\begin{tabular}{|c|c|c|c|c|c|c|c|c|}
\hline Study & Period & Country & Equity Risk & $\begin{array}{l}\text { Business Risk } \\
\text { (operating/asset risk) }\end{array}$ & Financial Risk & $\begin{array}{l}\text { Content of } \\
\text { Disclosures }\end{array}$ & $\begin{array}{l}\text { Disclosures } \\
\text { Included in } \\
\text { Equity Risk } \\
\text { Assessment }\end{array}$ & $\begin{array}{l}\text { Capitalisation } \\
\text { Method with } \\
\text { Higher } \\
\text { Explanatory } \\
\text { Power }\end{array}$ \\
\hline $\begin{array}{l}\text { Bowman } \\
\text { (1980a) }\end{array}$ & 1973 & US & $\begin{array}{l}\text { Market/systematic } \\
\text { risk: beta }\end{array}$ & Accounting beta & $\begin{array}{l}\text { Market value measure } \\
\text { of debt to equity }\end{array}$ & $\begin{array}{l}\text { Finance leases } \\
\text { disclosed prior to } \\
\text { capitalisation } \\
\text { requirements }\end{array}$ & Yes & $\begin{array}{l}\text { Not } \\
\text { applicable }\end{array}$ \\
\hline $\begin{array}{l}\text { Dhaliwal } \\
\text { (1986) }\end{array}$ & $1976-79$ & US & $\begin{array}{l}\text { Market/systematic } \\
\text { risk: beta }\end{array}$ & Accounting beta & $\begin{array}{l}\text { Book value of debt to } \\
\text { market value of equity }\end{array}$ & $\begin{array}{l}\text { Unfunded pension } \\
\text { liabilities }\end{array}$ & Yes & $\begin{array}{l}\text { Not } \\
\text { applicable }\end{array}$ \\
\hline $\begin{array}{l}\text { Imhoff, Lipe } \\
\text { and Wright } \\
\text { (1993) }\end{array}$ & 1984-89 & US & $\begin{array}{l}\text { Total risk: } \\
\text { standard deviation } \\
\text { of monthly returns }\end{array}$ & $\begin{array}{l}\text { Sample of companies } \\
\text { in the same } \\
\text { industries }\end{array}$ & $\begin{array}{l}\text { Book value of debt to } \\
\text { book value of total } \\
\text { assets }\end{array}$ & $\begin{array}{l}\text { Operating lease } \\
\text { liabilities }\end{array}$ & Yes & $\begin{array}{l}\text { Factor } \\
\text { method }\end{array}$ \\
\hline Ely (1995a) & 1987 & US & $\begin{array}{l}\text { Total risk: } \\
\text { standard deviation } \\
\text { of monthly returns }\end{array}$ & $\begin{array}{l}\text { Standard deviation } \\
\text { of annual return- } \\
\text { on-assets ratio }\end{array}$ & $\begin{array}{l}\text { Book value of debt to } \\
\text { market value of equity }\end{array}$ & $\begin{array}{l}\text { Operating lease } \\
\text { liabilities }\end{array}$ & Yes & Equivalent \\
\hline $\begin{array}{l}\text { Gallery and } \\
\text { Imhoff } \\
(1998)\end{array}$ & $1987-92$ & Australia & $\begin{array}{l}\text { Total risk: } \\
\text { standard deviation } \\
\text { of monthly returns }\end{array}$ & $\begin{array}{l}\text { Standard deviation of } \\
\text { operating income/ } \\
\text { sales ratio }\end{array}$ & $\begin{array}{l}\text { Book value of debt to } \\
\text { book value of total } \\
\text { assets }\end{array}$ & $\begin{array}{l}\text { Operating lease } \\
\text { liabilities }\end{array}$ & No & $\begin{array}{l}\text { Neither } \\
\text { significant }\end{array}$ \\
\hline
\end{tabular}


contribution to the association tests on market risk, concluding that ASR-147 lease data was reflected in security prices. Dhaliwal (1986) examined the relationship between market risk and another type of liability (unfunded pension obligations) disclosed but not recorded in company balance sheets. He found that the explanatory power of his model relating market (systematic) risk to financial and business risk (represented by accounting beta) improved when unfunded pension liabilities were included in his measure of financial leverage. Also, there was no significant difference in the relationship between marketperceived risk of the firm and unfunded pension liabilities (disclosed outside the balance sheet), compared to debt and other liabilities (disclosed on the balance sheet). He concluded that capital market participants appear to view unfunded pension liabilities in the same light as other debt liabilities when assessing the market risk of a firm.

The three remaining studies have specifically tested whether operating lease obligations are recognised in the market's assessment of equity risk. First, Imhoff et al. (1993) (hereafter ILW) examined the relationship between total risk reflected in stock price volatility and the debt-to-asset leverage ratio. Their analysis focused separately on two industries that were identified as having large amounts of long term operating leases, the airline and grocery industries. Firms in the same industry were used to provide a natural control for cross-sectional differences in operating risk. ILW use footnote disclosures to 'constructively capitalise' operating leases in line with capitalised finance leases, in order to calculate the appropriate adjustment to leverage ratios.

ILW evaluate two alternative methods of operating lease evaluation. First, their method of operating lease capitalisation involved applying estimates of average total life, remaining life and interest rate of firm's operating lease agreements to disclosures of minimum future operating lease payments. Second, they use an ad hoc multiplier adjustment for operating leases, the 'factor method'. Houlihan and Sondhi (1984) suggest that financial analysts may far more commonly employ the factor method. This method involved multiplying annual operating lease rentals by a factor of 8 to estimate the total operating lease liability. In the UK, Dresdner Kleinwort Benson (1998) note that 
the factor method is also one approach used by UK credit analysts and leasing experts to obtain a rough approximation of the total liability to which an annual operating lease rental obligation would equate. They suggest that multiplying the operating lease rental by 8 equates, for example, to discounting a constant rental charge at a rate of $8.5 \%$ over a 14 year period. However, previous researchers (Axelson, 1971; Imhoff, Lipe and Wright, 1995; and Gallery and Imhoff, 1998) have noted an overestimation of lease obligations by the factor method. Houlihan and Sondhi (1984) suggested that the problem of over-estimation has magnified over time, and could be detrimental to lessees by making them appear far more leveraged than they actually are. Dresdner Kleinwort Benson also question the accuracy of the 'factor 8' approach. They analytically identified a range of factor values from 6.9 to 10.2 times for leases maturing between the next ten to twenty years.

Initially, ILW estimated the correlation between firm risk and unadjusted and adjusted leverage ratios. Subsequent investigation used OLS regression analysis to determine whether the explanatory power of a model expressing the relationship between firm risk and financial leverage was improved when the operating lease adjustment to debt to asset ratio was introduced. ILW's data contained several annual observations for each firm. However, they used the mean measure of risk and leverage for each firm having three or more annual observations. This was, purportedly, to avoid the overstatement of the significance levels of pooled time-series cross-sectional tests, arising because firmyear observations are not independent. However, the use of averages significantly reduces sample size and the variability between observations. ILW used the natural logarithm of the standard deviation of returns, as their dependent variable, in an attempt to avoid any misspecification due to non-normality or heteroscedasticity.

The significant incremental explanatory power of ILW's operating lease adjustment supports the notion that US investors/analysts do appear to make use of 'off-balance sheet' operating lease disclosures when assessing a firm's risk. However, ILW found constructive capitalisation of operating leases to explain less of the intra-industry variation in risk than the ad hoc factor method. This implies that the operating lease valuation 
method that appears to be used in practice may not be accurate and is, therefore, a poor substitute for disclosing the true effect on the balance sheet. If these findings were to be repeated in the $\mathrm{UK}$, then the anticipated regulation requiring operating lease capitalisation might be expected to impact on firm risk assessments and hence lead to share price adjustments.

Second, Ely (1995a) extended the work of ILW by controlling explicitly for cross-sectional variation in operating/asset risk, which allowed her to undertake an analysis across rather than within industries. The standard deviation of return on assets was used to represent operating/asset risk, which allowed Ely to examine whether investors include operating leases in the return on assets (ROA) ratio, affecting equity risk through operating/ asset risk in addition to financial risk. In line with ILW, Ely also explored two alternative methods of evaluating operating leases. The first method, a variant of the constructive capitalisation method, involved estimation of the present value of operating lease obligations. In contrast to ILW, Ely assumed that firms enter into leases each year, causing the number of years since inception to be irrelevant. The validity of this assumption in the UK context is questionable. The operating lease obligations disclosed in footnotes relating to agreements having less than one year, between one and five years and over five years unexpired vary substantially (Edwards, 1997). This indicates that UK companies don't appear to maintain a constant proportion of operating lease finance. However, the general assumptions made by Ely in her operating lease capitalisation process were shown to be robust in the US context. (The correlations between her operating lease measure and alternative measures based on firm-specific estimates of lease term, interest rate and annual payments exceeded 0.9). Ely's second method involved multiplying the annual rental expense by a constant (both 6 and 8 were used).

Ely used OLS regression analysis to estimate her model relating equity risk to the accounting ratios 'return on assets' and 'debt to equity'. The debt to equity ratio was split according to debt reported on the balance sheet and operating lease liability estimated from footnotes. She found a significant relationship between equity risk and the debt to equity adjustment for operating leases. Also, the relationship between equity risk and 
operating/asset risk (measured as the standard deviation of ROA) was found to vary significantly when an operating lease adjustment was made to ROA. Ely's results provide additional evidence that US investors include operating lease asset and liability values when assessing equity risk. However, in contrast to ILW, Ely found the variation in risk explained by constructive capitalisation to be no different from that explained using the rental-based factor method.

Third, Gallery and Imhoff (1998) seek to contribute to the recognition versus disclosure debate by examining a specific set of footnote disclosures in a market setting other than the US. Their analysis is based on data for 89 of the top 100 Australian companies. In common with the prior two studies, two operating lease adjustment methods are investigated, the ILW (1991) constructive capitalisation method and the simple factor method. In contrast to ILW (1993) and Ely (1995a), they do not observe an association between operating lease footnote disclosures and a measure of equity risk (i.e., the operating lease adjustment variable is not significant when included in an OLS regression of equity risk on leverage and operating risk). This insignificance holds both for the full sample and for a sub-sample of 33 'high' operating lease companies.

Overall, there is convincing evidence that US investors do recognise operating leased assets and liabilities in their assessments of equity risk, while the limited evidence available in another setting (Australia) finds otherwise. The conflicting findings from these three studies may arise from differences in sample sizes (the Australian sample size was much smaller than Ely, 1995a), statistical problems (e.g., measurement error, omitted variables), differential risk premia across leased asset types, and/or differences in the market settings (e.g., the magnitude of information processing costs, the level of sophistication of analysts). Moreover, there is conflicting evidence regarding the operating lease evaluation method used by analysts (i.e., constructive capitalisation method or factor method). This could arise from many of the reasons given above. It could also arise from alternative controls for operating/asset risk differences across firms. Ely employed the standard deviation of ROA to control for differences between firms across industries, while ILW (1993) considered firms in the same industry. A 
combination of both controls might assist in the resolution of US evidence. Also, a process of diagnostic testing to assess the robustness of regression estimates would indicate the reliability of the findings of both studies. The present study considers such issues.

\section{RESEARCH METHODS}

The model used to investigate whether operating leases are recognised in the UK market's assessment of equity risk follows Ely (1995a), and derives from the financial theories of Modigliani and Miller (1958, and 1963) as applied by Bowman (1979) to accounting data.

Equity risk is predicted to have the following relationship with operating/asset risk and financial risk (assuming riskless debt, constant interest rates, and firm values equal to average expected earnings divided by some appropriate rate of return):

equity risk $=(1+(1-t)$ financial risk $) \times$ asset risk

equity risk $=$ asset risk $+(1-t)$ financial risk $\times$ asset risk

where $t$ is the marginal rate of tax. Reported financial risk measures based on firms' published balance sheets ignore liability elements, such as operating leases, which are off-balance sheet. If the financial markets consider that such liabilities contribute to firms' financial risk, an adjustment to the reported risk measure will be necessary:

$$
\begin{aligned}
\text { equity risk }= & \text { asset risk }+(1-t)\left(\text { fin } \text { risk }_{r e p}+\text { fin } \operatorname{risk}_{a d j}\right) \times \\
& \text { asset risk. }
\end{aligned}
$$

With the further assumption that marginal tax rates are constant across firms, this can be rearranged into the general crosssectional regression model:

$$
\begin{aligned}
\text { equity risk } & =\beta_{0}+\beta_{1} \text { asset risk }+\beta_{2} \text { fin } \text { risk }_{r e p} \times \text { asset risk } \\
& +\beta_{3} \text { fin risk } \text { adj }_{a \text { asset risk }}+\varepsilon .
\end{aligned}
$$

If operating leases are recognised in the market's assessment of equity risk, then the coefficient $\beta_{3}$ is expected to be significantly positive. Further, if operating leases are considered to be of 
similar risk to debt then $\beta_{3}$ should equal $\beta_{2}{ }^{12}$ For empirical testing, proxy measures are required for equity risk, operating/ asset risk and financial risk in addition to an estimate of the operating lease liabilities.

\section{(i) Equity Risk Proxies}

Total equity risk $\left(\sigma_{S}\right)$, rather than systematic/market risk (beta), is adopted as the dependent variable in the current study. ${ }^{13}$ This is appropriate in view of our focus on accounting measures of financial risk, since these reflect both systematic and firm-specific risk components. It is also consistent with other recent studies on lease disclosure. While the basic model describes an instantaneous relationship, reality requires consideration of the time dimension. One issue concerns the timing of variable measurement, in particular whether the dependent variable should be measured over the same time period as the independent variable(s), or at the beginning of this period. The market observes a particular level of current, and historical, operating/asset risk and financial risk presumably with the intent to forecast future expected equity risk. This suggests that a forward-looking ex ante measure of equity risk might be appropriate. Implied volatility from option pricing could provide such a measure, but this will itself have estimates of future gearing embedded by the market. There is also a major practical limitation to such an approach since there are relatively few companies with traded options in the UK, so potential sample size would be greatly reduced. The alternative approach of measurement of the dependent and independent variable(s) over a similar time period assumes that realised equity risk (and financial risk) measures are reasonably good proxies for ex ante forecasts.

The present study uses both approaches in measuring equity risk. In the spirit of ex ante risk measurement, one of the proxies (termed $\sigma_{S, 24,91}$ ) is calculated as the standard deviation of equity returns over a 24 month period ending in the month prior to the start of the firm's accounting period in 1991. The related financial risk is measured as an average over the subsequent three-year period to 1994 . The other proxy $\left(\sigma_{S, 60,94}\right)$ measures equity risk, contemporaneously with financial risk, as the 
standard deviation of equity returns over 60 months ending in 1994. This 60 month measure includes prior and matching periods, and also enables comparison with prior research. ${ }^{14}$ All measures are annualised before inclusion in the regression procedures.

\section{(ii) Operating/Asset Risk Proxies}

In prior research, operating/asset (business) risk has been proxied by accounting beta, industry dummies and variability in accounting return on assets (ROA); size has also been suggested as a suitable proxy. The main choice in the present study is variability in accounting return on assets $\left(\sigma_{\mathrm{ROA}}\right)$, measured as the standard deviation of annual ROA over a 7 year period, with ROA calculated by dividing earnings before interest and taxes by average total assets for a given year. ${ }^{15}$ The use of $\sigma_{\mathrm{ROA}}$ has support from theory (as long as return on assets reasonably reflects the firm's economic rate of return) and from empirical studies (Ely, 1995a; and 1995b). However, there is an issue with this measure in the present context. In addition to financial risk, accounting ROA may be adjusted by market participants if they treat business assets and liabilities acquired under operating lease agreements similarly to those recognised on the balance sheet. An indirect test of whether this occurs is carried out later, but prior research suggests that the impact on ROA is likely to be small relative to the adjustment in financial risk measures (Beattie et al., 1998). Nevertheless, this means that the test of the impact of operating leases on financial risk is a joint test of the impact on ROA.

To assess whether the results are sensitive to this issue, firm size and industry membership are used as alternative proxies for operating/asset risk. Generally, large firms are diversified either over different lines of business and/or geographically in contrast with small firms that rely on single product lines and/or single markets. Thus operating/asset risk is expected to be a negative, but not necessarily linear, function of firm size. The specific size measure adopted is the natural $\log$ of average total assets $(\ln (\overline{\mathrm{TA}}))$ measured over 1992-4. Different industries exhibit differing levels of business risk as a result of the nature of the goods or services supplied, the maturity of the industry and 
different levels of competition. Industry membership is assessed by incorporating dummy variables associated with inclusion in one of the major (nine) sectors in the sample.

\section{(iii) Financial Risk Proxies}

Although theory depicts financial risk as a function of the ratio of market value of debt to the market value of equity, many empirical studies have used book values for the numerator and/ or denominator. For example, Ely and others used the book value of debt because of the difficulty in finding reliable market values for many debt components and the impossibility of finding values for some. The use of the market value for equity can lead to increased volatility in the financial risk measure, and has encouraged some to use the book value of equity. However, ILW (1993) argue that using the book value of equity is not just a data issue but a statistical one. It creates econometric problems because it can be near zero or negative for a given firm-year observation. As a consequence, they prefer the book value of assets as their leverage ratio denominator. Similarly, the present study uses the book value of total debt to total assets, measured as an average over the three years $1992-4\left(\overline{\mathrm{D}_{\text {rep }} / \mathrm{TA}}\right)$ as the main proxy for financial risk but also considers the (BV total debt)/ (MV equity) proxy as a single period measure for $1994\left(\mathrm{D}_{\text {rep }} /\right.$ E). ${ }^{16}$

\section{(iv) Estimates of Operating Lease Liabilities}

An estimate of the adjustment to financial risk (fin risk ${ }_{a d j}$ ) for operating leases is required. Two methods were adopted. In the first, the present value of operating lease liabilities (PVOL) for each sample company was obtained from a constructive capitalisation procedure, suggested by ILW (1991), as adapted by Beattie et al. (1998). This requires assumptions to be made regarding the average remaining lease life and an appropriate discount rate. Estimation of the value of the unrecorded lease asset requires further assumptions regarding the average total lease life and the depreciation method. The procedure incorporates company-specific assumptions of average remaining and total lease life, and distinguishes between the two asset 
classes ('land and buildings' and 'other') disclosed in the UK. Having investigated short term borrowing rates over the study period, a discount rate of $10 \%$ was selected as most appropriate. The operating lease liability is estimated as the present value of the expected future minimum lease rental payments discounted at $10 \%$. Further details of the capitalisation procedure can be found in Beattie et al. (1998) and an illustration of its application to a particular company is given in the Appendix to this paper. Results from prior research were found to be robust with respect to the assumptions used in the capitalisation procedure, and a check on the sensitivity of the present results confirmed this. ${ }^{17}$

An alternative heuristic for the estimation of operating lease liabilities is sometimes employed by investment analysts. This involves multiplying the reported operating lease expense by a particular factor as a simplification of the present value calculation. Analysts using this so-called 'factor method' typically use a factor of 8 in the UK (Dresdner Kleinwort Benson, 1998, p. 4) while both 6 and 8 are common in the US (Ely, 1995a). The second estimate of operating lease liabilities, based on the 'factor 8 ' method, was used to assess whether the UK market's assessment of equity risk is better explained using this estimate than the more complex constructive capitalisation procedure. The proxy (OLR) was based on the expense actually reported in the footnote to the profit and loss account. For some companies, this will include some short-term rentals, lease contracts that have terminated during the year and perhaps contingent lease payments. $^{18}$

Incorporating the main proxies into equation (3) gives the following cross-sectional regression model for estimation:

$$
\begin{aligned}
\sigma_{S, 60,94} & =\beta_{0}+\beta_{1} \sigma_{\mathrm{ROA}}+\beta_{2} \overline{D_{\text {rep }} / \mathrm{TA}} \times \sigma_{\mathrm{ROA}} \\
& +\beta_{3} \overline{\mathrm{PVOL} / \mathrm{TA}} \times \sigma_{\mathrm{ROA}}+\varepsilon .
\end{aligned}
$$

\section{(v) Impact on Operating/Asset Risk}

Constructive capitalisation of operating leases may also affect ROA, the proxy used in this study for operating/asset risk, so the impact on this was also investigated. Direct assessment of the measure of operating/asset risk adjusted for operating leases, 
$\sigma_{\mathrm{ROA} a d j}$, would require the estimation of PVOL and the profit and loss account impact of capitalisation for at least seven years. In the absence of such information an alternative approach was adopted. Following Ely (1995a), it is first assumed that the relationship between reported ROA and ROA adjusted for the impact of operating lease capitalisation is as follows:

$$
\mathrm{ROA}_{r e p}=\mathrm{ROA}_{a d j} \times \rho,
$$

where $\mathrm{ROA}_{\text {rep }}=\mathrm{EBI}_{\text {rep }} / \mathrm{TA}_{\text {rep }}=$ earnings before interest $/$ total assets reported;

$\mathrm{ROA}_{a d j}=\mathrm{EBI}_{a d j} / \mathrm{TA} \mathrm{Adj}$;

$\mathrm{EBI}_{a d j}=\mathrm{EBI}_{r e p}+$ operating lease rental - depreciation;

$\mathrm{TA}_{a d j}=\mathrm{TA}_{\text {rep }}+$ operating lease assets; and

$\rho \quad=$ multiplicative relationship between the two.

If the effect of capitalisation is to reduce ROA, then $\rho$ will be greater than 1 and vice versa. The impact on $\sigma_{\mathrm{ROA}}$ will depend on the time series properties of each firm's $\rho$; this will depend mainly on the changes in the firm's lease portfolio over time.

On the assumption that a firm enters into new leases each year, $\rho$ is constant and $\sigma_{\mathrm{ROA} a d j}$ will be related to the reported operating/asset risk as follows (Ely, 1995a):

$$
\sigma_{\mathrm{ROA} a d j}=1 / \rho \times \sigma_{\mathrm{ROA} r e p} .
$$

Substituting this expression for $\sigma_{\mathrm{ROA}, a d j}$ into equation (4) leads to:

$$
\begin{aligned}
\sigma_{S, 60,94} & =b_{0}+b_{1} \sigma_{\mathrm{ROA} r e p}+b_{2} \overline{D_{\text {rep }} / \mathrm{TA}} \times \sigma_{\mathrm{ROA} r e p} \\
& +b_{3} \overline{\mathrm{PVOL} / \mathrm{TA}} \times \sigma_{\mathrm{ROA} r e p}+\varepsilon
\end{aligned}
$$

where $b_{1}, b_{2}$ and $b_{3}$ are each now functions of $\rho$.

If investors adjust ROA for operating leases when assessing operating/asset risk, then variations in $\rho$ across companies will result in significant differences in the coefficients $b_{1}, b_{2}$ and $b_{3}$. In the absence of direct estimates of $\sigma_{\mathrm{ROA} a d j}$, an indirect test can therefore be constructed by grouping companies on the basis of $\rho$. The value of $\rho$ is calculated for each company in the sample for 1994. Companies are then classified into one of three groups: companies without operating leases $(\rho=1)$, companies with $\rho$ values below 1 (denoted $L$ ) and companies with $\rho$ values above 1 (denoted $H$ ). Interactive dummy variables are introduced for the 
latter two groups to test whether the coefficients vary across $\rho$ as predicted in the following model:

$$
\begin{aligned}
\sigma_{S, 60,94}=\beta_{0} & +\beta_{1} \sigma_{R O A}+\beta_{1 L} \sigma_{\mathrm{ROA}} \times L+\beta_{1 H} \sigma_{\mathrm{ROA}} \times H \\
& +\beta_{2} \overline{D_{\text {rep }} / \mathrm{TA}} \times \sigma_{\mathrm{ROA}}+\beta_{2 L} \overline{D_{\text {rep }} / \mathrm{TA}} \times \sigma_{\mathrm{ROA}} \times L \\
& +\beta_{2 H} \overline{D_{\text {rep }} / \mathrm{TA}} \times \sigma_{\mathrm{ROA}} \times H+\beta_{3 L} \overline{\mathrm{PVOL} / \mathrm{TA}} \times \sigma_{\mathrm{ROA}} \times L \\
& +\beta_{3 H} \overline{\mathrm{PVOL} / \mathrm{TA}} \times \sigma_{\mathrm{ROA}} \times H
\end{aligned}
$$

where $L=1$ for $\rho<1$, and $=0$ otherwise;

$H=1$ for $\rho>1$, and $=0$ otherwise.

For companies with no operating leases, $\rho=1$, and both $L$ and $H$ are 0 .

If the effect of operating lease capitalisation is to reduce ROA, then $\rho>1$, and the adjusted operating/asset risk measure $\sigma_{\mathrm{ROA} a d j}$ will be smaller than the reported variability. This reduced variability should, in turn, be reflected in reduced equity risk $\sigma_{S}$. Thus, for companies with $\rho>1$, the coefficients $\beta_{1 H}$ and $\beta_{2 H}$ are expected to be negative and the increased operating/asset risk associated with companies with $\rho<1$ should lead to positive $\beta_{1 L}$ and $\beta_{2 L}$ coefficients.

In effect, the variable $(\overline{\mathrm{PVOL} / \mathrm{TA}}) \times \sigma_{\mathrm{ROA}}$ is automatically excluded from the model for companies having no operating leases since PVOL is zero, so $\beta_{3}$ cannot be estimated. This means that coefficients $\beta_{3 L}$ and $\beta_{3 H}$ are not incremental adjustments to $\beta_{3}$. Instead, they each measure the direct relationship between the operating lease adjustment (PVOL) and equity risk $\left(\sigma_{S}\right)$ for the groups of low $(L)$ and high $(H) \rho$ companies. Thus, a positive relationship is expected for both $\beta_{3 L}$ and $\beta_{3 H}$ as a result of the direct PVOL $-\sigma_{S}$ relationship, but the ROA effect is expected to increase the $\beta_{3 L}$ coefficient but reduce the $\beta_{3 H}$ coefficient. Overall, if the PVOL effect is dominant, as expected, both coefficients would be expected to be positive, but $\beta_{3 L}$ should be greater than $\beta_{3 H}$.

\section{DATA}

Some of the data employed in this study, originally obtained from Datastream or manually extracted from microfiche sets of company financial statements supplied by Companies House, 
was available from a database constructed by Edwards (1997) to determine the impact of constructive operating lease capitalisation on key accounting ratios. The database contains selected profit and loss and balance sheet items, together with operating lease obligations extracted from the footnotes to the financial statements. It spans the years 1981 to 1994 for a randomly selected sample of 300 UK commercial and industrial (i.e., non-financial) listed companies and covers a wide size range and industry distribution. ${ }^{19}$ Additional variables required for this study, including stock returns, market returns and the market value of equity were collected from Datastream and added to the original database. Of the 232 companies in the database for 1994, 161 possessed all the relevant data over the 1987-94 period, the focus of the present study. The proxy variables used, their definitions and, where appropriate, their Datastream identifications, are summarised in Table 2.

\section{RESULTS}

Summary statistics of the variables for the 156 companies ${ }^{20}$ in the sample are reported in Table 3. A key feature is that the present sample is not biased towards large 'blue-chip' companies, reflecting the essentially random selection process. This is indicated in the wide size range (£3m through $£ 21,900 \mathrm{~m}$, based on average total assets) and the relatively small average size $($ mean $=£ 774 \mathrm{~m}$, median $=£ 80 \mathrm{~m})$. The large difference between mean and median is as expected for the significantly skewed size distribution in both sample and population. On average, the sample companies had an estimated mean $£ 61 \mathrm{~m}$ of operating lease liabilities (PVOL) in 1994, representing $15 \%$ of balance sheet assets (PVOL/TA) and $26 \%$ of equity market value (PVOL/E). The heuristic 'factor 8' method (OLR) yields a much larger mean estimate of $£ 102 \mathrm{~m}$ for operating lease liabilities. The larger estimate based on the factor method has been found in previous studies, and may be overstated, partly because of the multiple of 8 used and partly because it gives full weight to short-term rentals. On the other hand, the estimate based on PVOL ignores contingent rentals (since these are not part of the minimum lease payments recorded in the balance 
Table 2

Variable Definition and Datastream/Other Identifications

\begin{tabular}{|c|c|c|c|}
\hline Variable & Notation & Definition ${ }^{1}$ & Datastream/Other Identification \\
\hline Equity risk & $\sigma_{s, n, Y Y}$ & $\begin{array}{l}\text { Standard deviation of monthly } \\
\text { returns for } n \text { months prior to each } \\
\text { company's } 19 Y Y \text { year end, annualised } \\
\text { by multiplying by the square root of } 12\end{array}$ & $\begin{array}{l}\mathrm{MR}_{t}=\left(\mathrm{RI}_{t}-\mathrm{RI}_{t-1}\right) / \mathrm{RI}_{t-1} \\
\mathrm{MR}_{t}=\text { return for month } t \\
\mathrm{RI}_{t}=\text { returns index at end month } t \\
\mathrm{RI}_{t-1}=\text { returns index at end month } t-1\end{array}$ \\
\hline \multirow[t]{3}{*}{ Operating/asset risk } & $\sigma_{\mathrm{ROA}}$ & $\begin{array}{l}\text { Standard deviation of accounting return } \\
\text { on assets (ROA) over } 7 \text { years based } \\
\text { on average total assets. }\end{array}$ & $\begin{array}{l}\mathrm{ROA}=(157+153) / 0.5\left(392_{t}+392_{t-1}\right) \\
157=\text { Pre-tax profit adjusted } \\
153=\text { Interest payable } \\
392=\text { Total assets }\end{array}$ \\
\hline & $\ln (\overline{\mathrm{TA}})$ & $\begin{array}{l}\text { Natural log of average total assets } \\
\text { measured over 1992-4 }\end{array}$ & $\ln \left(\left(392_{94}+392_{93}+392_{92}\right) / 3\right)$ \\
\hline & $\begin{array}{l}\text { industry dummies } \\
\text { (for major sectors) }\end{array}$ & $\begin{aligned} \text { Dummy } & =1 \text { if company is within sector } \\
( & =0, \text { otherwise })\end{aligned}$ & $\begin{array}{l}\text { Major sectors: building, electricals } \\
\text { retail, engineering, textiles, breweries, } \\
\text { motors, leisure and household goods }\end{array}$ \\
\hline \multicolumn{4}{|l|}{ Financial risk } \\
\hline \multirow[t]{2}{*}{ Total debt/Assets } & $D_{r e p} / \mathrm{TA}$ & $\begin{array}{l}\text { Long term }+ \text { short term loans } \\
+ \text { overdrafts divided by total assets. }\end{array}$ & $\begin{array}{l}(321+309) / 392 \\
321=\text { Total loan capital } \\
309=\text { Borrowings repayable within } 1 \text { year } \\
392=\text { Total assets }\end{array}$ \\
\hline & $\overline{D_{\text {rep }} / \mathrm{TA}}$ & Average of annual $D_{\text {rep }} /$ TA over $1992-4$ & \\
\hline Total debt/Equity & $D_{\text {rep }} / E$ & $\begin{array}{l}\text { Long term }+ \text { short term loans }+ \text { overdrafts } \\
\text { divided by market value of equity }\end{array}$ & $\begin{array}{l}(321+309) / \text { HMV } \\
\text { HMV }=\text { Historical market value of equity }\end{array}$ \\
\hline
\end{tabular}

Long term + short term loans + overdrafts ivided by market value of equity

\footnotetext{
$(321+309) / \mathrm{HMV}$
} 
Financial risk adjustment for operating lease liability (see also Appendix):

PVOL/Assets

PVOL/TA

Present value of operating lease liability, estimated using constructive capitalisation divided by total assets

$\overline{\mathrm{PVOL} / \mathrm{TA}}$

Average of annual PVOL/TA over 1992-4

Operating lease OLR/TA

rental/Assets

$\overline{\mathrm{OLR} / \mathrm{TA}}$

PVOL/Equity

PVOL/E
Operating lease $1994 \mathrm{P} \& \mathrm{~L}$ expense

divided by total assets

Average of annual OLR/TA over 1992-4

Present value of operating lease liability, estimated using constructive capitalisation, divided by market value of equity
PVOL / 392

OLR / 392

PVOL / HMV 
Table 3

Summary Statistics

\begin{tabular}{|c|c|c|c|c|c|}
\hline & Mean & Median & Min. & Max. & $\begin{array}{l}\text { Stan. } \\
\text { Dev. }\end{array}$ \\
\hline Size (average total assets) $£ \mathrm{~m}$ & 773.6 & 80.2 & 3.0 & 21,900 & $2,461.0$ \\
\hline Market value equity $(E) £ \mathrm{~m}$ & 491.0 & 78.7 & 0.4 & 6,435 & $1,055.1$ \\
\hline $\begin{array}{l}\text { Operating lease liability } \\
\text { (PVOL) £m }\end{array}$ & 61.1 & 5.8 & 0.0 & 1,598 & 187.4 \\
\hline $\begin{array}{l}\text { Operating lease liability } \\
\text { (OLR, 'factor } 8 \text { ' method) }\end{array}$ & 101.9 & 12.8 & 0.0 & 1.816 & 259. \\
\hline Equity risk $\left(\sigma_{S, 60,94}\right)$ & 0.3753 & 0.3333 & 0.1146 & 1.1633 & 0.1660 \\
\hline Equity risk $\left(\sigma_{S, 24,91}\right)$ & 0.3500 & 0.3080 & 0.0486 & 1.0534 & 0.1606 \\
\hline Operating/asset risk $\left(\sigma_{\mathrm{RO}}\right.$ & 0.0487 & 0.0391 & 0.0035 & 0.1935 & 0.0382 \\
\hline Financial risk ( $\left.\underline{D_{r e p} / \mathrm{TA}}\right)$ & 0.1785 & 0.1662 & 0.0000 & 1.2252 & 0.1473 \\
\hline Financial risk $\left(\overline{D_{r e p} / \mathrm{TA}}\right)$ & 0.1892 & 0.1703 & 0.0000 & 1.1551 & 0.1528 \\
\hline Financial risk $\left(D_{\text {rep }} / E\right)$ & 0.4340 & 0.1983 & 0.0000 & 11.2678 & 1.0117 \\
\hline Operating lease adj: (PVOL/TA) & 0.1476 & 0.0668 & 0.0000 & 1.9186 & 0.2928 \\
\hline Operating lease adj: $(\overline{\mathrm{PVOL} / \mathrm{TA}})$ & 0.1487 & 0.0676 & 0.0000 & 1.8899 & 0.2896 \\
\hline Operating lease adj: (PVOL/E) & 0.2606 & 0.0708 & 0.0000 & 4.4770 & 0.6075 \\
\hline
\end{tabular}

Notes:

${ }_{1}^{1}$ All variables measured at 1994 year end; overbar indicates average measure over 3 years 1992-4.

sheet footnote) and may understate the liability. The number of companies using operating lease finance was 139 out of 156 (89\%), compared with $68 \%$ of the sample of US companies in Ely (1995a). The median PVOL/TA is over $70 \%$ higher (0.067 vs. 0.039) than in Ely (1995a) though the median PVOL/E is closer (0.071 vs. 0.063$)$. Overall, these statistics indicate greater use of operating leases in the UK sample than in Ely's earlier US study.

Further comparisons with Ely are warranted. Our median equity risk $\left(\sigma_{S, 60,94}\right)$ is quite similar $(0.38$ vs. 0.33 in Ely after annualising), but the median level of operating risk $\left(\sigma_{\mathrm{ROA}}\right)$ in the present study is somewhat higher (0.049 vs. 0.025 in Ely), reflecting the greater return variability expected for the smaller, less diversified companies included in our sample. ${ }^{21}$ A more striking distinction is observed in the financial risk proxies, with a median $D_{\text {rep }} / E$ of 0.20 in the UK compared with 0.99 in the US study. Ely did not report a figure for $D_{\text {rep }} /$ TA but this can be estimated at about 0.60 , based on the data provided; this compares with our median of 0.17 . The Ely measures are based on total liabilities (including accounts payable and other non- 
debt items) in contrast to our total debt measure. While this accounts for some of the difference, the higher debt level in the US remains. These statistics are consistent with the international capital structure comparison which, based on a consistent measure of total debt (rather than total liabilities) for 1991, reported mean $\mathrm{D} / \mathrm{TA}$ of 0.22 for the UK compared with 0.31 for the US (Table II, Rajan and Zingales, 1995).

\section{(i) OLS Regression Models}

Table 4 reports results from the OLS regressions (using SHAZAM $\mathrm{v}$ 8.0) with $\sigma_{\mathrm{ROA}}$ as the proxy for operating/asset risk. In models 1-3 the financial risk and operating lease variables are averages over the three years 1992-4. Model 1 shows the relationship between equity risk $\left(\sigma_{S, 60,94}\right)$ and operating/asset risk and financial risk before any adjustment to financial risk for operating leases. Both explanatory variables are significant at the $1 \%$ level, and $52.9 \%$ of the cross-sectional variation in equity risk is explained. Models 2 and 3 consider operating lease adjustments based on constructive capitalisation (PVOL) and the 'factor 8' method (OLR), respectively. If the capital market incorporates the operating lease footnote disclosures in its assessment of equity risk, then the coefficients on these variables should be reliably positive. In model 2 , the addition of the PVOL variable contributes significantly to the explanatory power of the model as evidenced by the significantly positive coefficient (at the $1 \%$ level $)^{22}$ and the increase in adj $R^{2}$. Similarly, in model 3 , the coefficient on OLR is significantly positive but at the $5 \%$ level. These results imply that operating leases are currently recognised in the UK market's assessment of equity risk. Although the significance of the OLR coefficient is slightly lower, there is little evidence that the market favours one method of estimating operating lease liabilities over the other.

If, for lessee companies, the risks associated with operating leases are equivalent to those associated with debt, then the coefficients on debt $\left(\beta_{2}\right)$ and operating lease adjustment $\left(\beta_{3}\right)$ are expected to be equal. Here, $\beta_{3}$ estimates for both PVOL (1.139) and OLR (0.951) are significantly smaller, at the $1 \%$ level, than $\beta_{2}$ (5.358 and 5.341 respectively). Overall, these results indicate that investors/analysts view operating leases as property rights, 
Table 4

OLS Multivariate Regressions with Total Equity Risk $\left(\sigma_{s}\right)$ as Dependent Variable

\begin{tabular}{|c|c|c|c|c|c|c|}
\hline \multirow{2}{*}{$\begin{array}{l}\text { Dependent Variable } \\
\text { Model Number: } \\
\text { Independent Variables }\end{array}$} & \multicolumn{5}{|c|}{$\sigma_{S, 60,94}$} & \multirow{2}{*}{$\begin{array}{l}\sigma_{S, 24,91} \\
6 \\
\text { Coeff. } \\
\text { t-stat. }\end{array}$} \\
\hline & $\begin{array}{l}1 \\
\text { Coeff. } \\
\text { t-stat. }\end{array}$ & $\begin{array}{l}2 \\
\text { Coeff. } \\
\text { t-stat. }\end{array}$ & $\begin{array}{l}3 \\
\text { Coeff. } \\
\text { t-stat. }\end{array}$ & $\begin{array}{l}4 \\
\text { Coeff. } \\
\text { t-stat. }\end{array}$ & $\begin{array}{l}5 \\
\text { Coeff. } \\
\text { t-stat. }\end{array}$ & \\
\hline $\begin{array}{l}\text { Operating (asset) risk } \\
\sigma_{\mathrm{ROA}}\end{array}$ & $\begin{array}{l}1.564 \\
4.68^{* * *}\end{array}$ & $\begin{array}{l}1.339 \\
4.19 * * *\end{array}$ & $\begin{array}{l}1.244 \\
3.88^{* * * *}\end{array}$ & $\begin{array}{l}1.288 \\
3.71 * * *\end{array}$ & $\begin{array}{l}2.335 \\
5.56 * * *\end{array}$ & $\begin{array}{l}0.780 \\
2.14 * *\end{array}$ \\
\hline$\left.\frac{\text { Financial risk }}{\left(D_{\text {rep }} / \mathrm{TA}\right.}\right) \times \sigma_{\mathrm{ROA}}$ & $\begin{array}{l}5.358 \\
6.74 * * *\end{array}$ & $\begin{array}{l}5.341 \\
7.11 * * *\end{array}$ & $\begin{array}{l}5.388 \\
7.52 * * *\end{array}$ & & & $\begin{array}{l}4.351 \\
7.46 * * *\end{array}$ \\
\hline$\left(D_{r e p} / \mathrm{TA}\right) \times \sigma_{\mathrm{ROA}}$ & & 1.11 & 1.52 & $\begin{array}{l}7.875 \\
4.91 * * *\end{array}$ & & 1.40 .4$. \\
\hline$\left(D_{\text {rep }} / E\right) \times \sigma_{\mathrm{ROA}}$ & & & & & $\begin{array}{l}1.007 \\
1.74 * *\end{array}$ & \\
\hline $\begin{array}{l}\text { Operating lease adj } \\
(\overline{\mathrm{PVOL} / \mathrm{TA}}) \times \sigma_{\mathrm{ROA}}\end{array}$ & & $\begin{array}{l}1.139 \\
3.05 * * *\end{array}$ & & & & $\begin{array}{l}1.511 \\
2.51 * * *\end{array}$ \\
\hline$(\mathrm{PVOL} / \mathrm{TA}) \times \sigma_{\mathrm{ROA}}$ & & & & $\begin{array}{l}1.020 \\
3.12 * * *\end{array}$ & & \\
\hline$(\mathrm{PVOL} / \mathrm{E}) \times \sigma_{\mathrm{ROA}}$ & & & & & $\begin{array}{l}0.887 \\
2.49 * * *\end{array}$ & \\
\hline$(\overline{\mathrm{OLR} / \mathrm{TA}}) \times \sigma_{\mathrm{ROA}}$ & & & $\begin{array}{l}0.951 \\
2.15 * *\end{array}$ & & & \\
\hline constant & $\begin{array}{l}0.248 \\
18.79 * * *\end{array}$ & $\begin{array}{c}0.250 \\
19.89 * * *\end{array}$ & $\begin{array}{c}0.251 \\
19.71^{* * *}\end{array}$ & $\begin{array}{c}0.238 \\
18.35 * * *\end{array}$ & $\begin{array}{c}0.232 \\
13.40^{* * *}\end{array}$ & $\begin{array}{c}0.258 \\
17.34 * * *\end{array}$ \\
\hline$n$ & 156 & 156 & 156 & 156 & 156 & 156 \\
\hline Adj Rsq & $\begin{array}{c}0.529 \\
87.99 * * *\end{array}$ & $\begin{array}{l}0.545 \\
6976 * * *\end{array}$ & $\begin{array}{l}0.544 \\
6958 * *\end{array}$ & $\begin{array}{c}0.544 \\
6959 * * *\end{array}$ & $\begin{array}{c}0.459 \\
4476 * * *\end{array}$ & $\begin{array}{c}0.355 \\
9941 * * *\end{array}$ \\
\hline Jarque-Bera & $48.56^{* * * *}$ & $61.51 * * *$ & $\begin{array}{l}62.58 \% * \\
61.72 * * *\end{array}$ & $36.24 * * *$ & $52.07 * * *$ & $9.16^{* * *}$ \\
\hline Breusch-Pagan-Godfrey & $17.93 * * *$ & $15.19 * * *$ & $16.90 * * *$ & $32.88 * * *$ & $73.63^{* * *}$ & $8.10^{* *}$ \\
\hline
\end{tabular}

Note:

$* * *, * *$ and $*$ represent significance at the $1 \%, 5 \%$ and $10 \%$ levels respectively (1-tail) using White's (1980) heteroskedastic-consistent covariance matrix estimation to adjust for heteroskedasticity.

taking them into account in their assessment of equity risk. This is consistent with previous UK empirical research, which found that companies' total lease obligations and non-leasing debt were substitutes (Beattie et al., 2000). The directional difference between $\beta_{3}$ and $\beta_{2}$ suggests that the market perceives operating leases to be less risky than debt, consistent with Beattie et al.'s observation that companies act as if company management perceive operating lease obligations as less risky than debt. 
Models 4 and 5 in Table 4 consider alternative financial risk proxies. In model 4 , the financial risk $\left(D_{\text {rep }} / \mathrm{TA}\right)$ and operating lease variable (PVOL/TA) are single period measures as at each company's 1994 year-end. The results are almost identical to those based on 3-year averages (model 3). Model 5 also uses single period measures for financial risk and operating lease adjustment but adopts total debt/market value of equity $\left(D_{\text {rep }} / E\right)$ as the proxy for financial risk, similar to Ely (1995a). The adj $R^{2}$ reduces to $46 \%$ and while the operating/asset risk coefficient is larger and has a higher $t$-statistic, the size and significance of the financial risk coefficient are reduced in comparison with the total assets-based models. The PVOL coefficient is slightly smaller but remains significantly positive at the $1 \%$ level.

The results from the US study by Ely (1995a) were broadly similar to those presented here. The overall explanatory power of the US models was somewhat lower (adj $\left.R^{2}=39 \%\right)$, notwithstanding the larger sample size $(n=314)$. The significance of the US financial risk variable was higher ( $t$-stat. $=5.72$ ), probably reflecting the higher levels of leverage in the US sample. However, the significance of the operating/asset risk $(t$-stat. $=5.70)$ and operating lease coefficients $(t$-stat. $=2.58)$ were very similar to our UK results. A further similarity is that Ely found no difference between the operating lease adjustment based on rental expense (i.e., the factor method) and that based on constructive capitalisation.

Finally in Table 4, model 6 presents the results from using, as the dependent variable, an ex ante equity risk proxy. For this, equity risk $\left(\sigma_{S, 24,91}\right)$ is measured over a period of 24 months prior to the start of the first of the three accounting periods over which the average financial risk and operating lease adjustment variables are calculated. Compared with the 'roughly contemporaneous' model 2 , the results are very similar. While the overall explanatory power $\left(\operatorname{adj} R^{2}=36 \%\right)$ and the size and significance of $\sigma_{\mathrm{ROA}}$ are lower, the financial risk and operating lease adjustments are not greatly affected.

\section{(ii) Alternative Operating/Asset Risk Proxies}

Evaluating operating leases as property rights also affects the proxy used thus far for operating/asset risk through ROA. To 
check whether our results are sensitive to this, alternative proxies that avoid this situation are assessed. Table 5 presents results for proxies based on size (model 7), industry dummies (model 8) and for a combination of all three proxies (model 9), with the previous results based on $\sigma_{\mathrm{ROA}}$ (model 2) for comparison.

In model 7 , the negative coefficient on $\ln (\overline{\mathrm{TA}})$ is as predicted, with the lower operating risk from large firm diversification reflected in reduced equity risk. The reduction in significance of the financial risk variable is probably the result of size also proxying for financial risk (large companies have higher leverage). Care has to be exercised in interpreting the individual industry dummy coefficients in model 8 as the constant term incorporates the industry effect for all non-dummy sectors. However, the coefficients generally have the expected sign and the significant positive coefficient (high risk) on the building sector dummy and negative coefficients on retail and breweries are intuitively supportable. The lower explanatory power of these two models suggests perhaps that $\sigma_{\mathrm{ROA}}$ is a more powerful proxy for operating/asset risk. One further attribute of models 7 through 9 is that the significance of the intercept term is greatly reduced, suggesting that size and industry do capture important features associated with equity risk.

The main feature of the results in Table 5 is the consistently positive and statistically significant coefficient on the operating lease adjustment across all proxies. While this does not provide evidence on whether the market adjusts ROA for operating leases, it strongly affirms that the evidence that the market adjusts financial risk measures is robust to the proxy adopted for operating/asset risk.

\section{(iii) Diagnostics}

In addition to the assessment of influential observations (see note 20), further diagnostic procedures were adopted. First, a set of collinearity diagnostics (Belsley et al., 1980) was computed. The bivariate correlations between independent variables did not exceed 0.3 , the variance inflation factors were less than 10 in all cases, and the condition number was well below 30 . From these, it was concluded that multicollinearity was not a problem in the current study. Testing for heteroskedasticity was carried out, and 
Table 5

OLS Multivariate Regressions for Alternative Operating (Asset) Risk Proxies with Total Equity Risk $\left(\sigma_{s}\right)$ as Dependent Variable

\begin{tabular}{|c|c|c|c|c|}
\hline \multirow{2}{*}{$\begin{array}{l}\text { Dependent Variable } \\
\text { Model Number: } \\
\text { Independent Variables }\end{array}$} & \multicolumn{3}{|c|}{$\sigma_{S, 60,94}$} & \multirow[b]{2}{*}{$\begin{array}{l}9 \\
\text { Coeff. } \\
\text { t-stat. }\end{array}$} \\
\hline & $\begin{array}{l}2 \\
\text { Coeff. } \\
\text { t-stat. }\end{array}$ & $\begin{array}{l}7 \\
\text { Coeff. } \\
\text { t-stat. }\end{array}$ & $\begin{array}{l}8 \\
\text { Coeff. } \\
\text { t-stat. }\end{array}$ & \\
\hline \multicolumn{5}{|l|}{ Operating (asset) risk } \\
\hline$\sigma_{\mathrm{ROA}}$ & $\begin{array}{l}1.339 \\
4.19 * * *\end{array}$ & & & $\begin{array}{l}1.136 \\
3.30^{* * * *}\end{array}$ \\
\hline $\ln (\overline{\mathrm{TA}})$ & & $\begin{array}{l}-0.0483 \\
-5 . .49 * * *\end{array}$ & & $\begin{array}{l}-0.0074 \\
-1.39 *\end{array}$ \\
\hline $\begin{array}{l}9 \text { industry dummies } \\
\text { building } \\
\text { electricals } \\
\text { retail } \\
\text { engineering } \\
\text { textiles } \\
\text { breweries } \\
\text { motors } \\
\text { leisure } \\
\text { household goods }\end{array}$ & & & $\begin{array}{l}0.0943 * * \\
-0.0021 \\
-0.1474 * * * \\
0.0148 \\
-0.0246 \\
-0.1017 * * * \\
-0.0454 \\
-0.0424 \\
-0.0214\end{array}$ & $\begin{array}{c}0.0003 \\
-0.0275 \\
-0.0262 \\
-0.0088 \\
-0.0718^{*} \\
-0.0537^{* *} \\
-0.0032 \\
0.0011 \\
-0.0488\end{array}$ \\
\hline 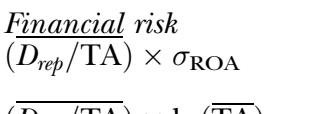 & $\begin{array}{l}5.341 \\
7.11^{* * * *}\end{array}$ & & & $\begin{array}{l}5.172 \\
7.38 * * *\end{array}$ \\
\hline $\begin{array}{l}\left(\overline{D_{\text {rep }} / \mathrm{TA}}\right) \times \ln (\overline{\mathrm{TA}}) \\
\left(\overline{D_{\text {rep }} / \mathrm{TA}}\right)\end{array}$ & & $\begin{array}{l}0.0375 \\
2.64 * * *\end{array}$ & $\begin{array}{l}0.372 \\
2.72 * * *\end{array}$ & \\
\hline $\begin{array}{l}\text { Operating lease adj } \\
(\overline{\mathrm{PVOL} / \mathrm{TA}}) \times \sigma_{\mathrm{ROA}}\end{array}$ & $\begin{array}{l}1.139 \\
3.05 * * *\end{array}$ & & & $\begin{array}{l}1.135 \\
2.66^{* * * *}\end{array}$ \\
\hline$(\overline{\mathrm{PVOL} / \mathrm{TA}}) \times \ln (\overline{\mathrm{TA}})$ & & $\begin{array}{l}0.0083 \\
3.42 * * *\end{array}$ & & \\
\hline$(\overline{\mathrm{PVOL} / \mathrm{TA}})$ & & & $\begin{array}{l}0.203 \\
4.36^{* * * *}\end{array}$ & \\
\hline constant & $\begin{array}{c}0.250 \\
19.89 * * *\end{array}$ & $\begin{array}{l}0.7489 \\
9.95 * * *\end{array}$ & $\begin{array}{l}0.290 \\
8.65 * * *\end{array}$ & $\begin{array}{l}0.364 \\
4.93 * * *\end{array}$ \\
\hline$n$ & 156 & 156 & 156 & 156 \\
\hline Adj Rsq & 0.545 & 0.256 & 0.227 & 0.533 \\
\hline$F$ & $62.76 * * *$ & $18.76^{* * *}$ & $5.13 * * *$ & 14.60 *** \\
\hline Jarque-Bera & $61.51 * * *$ & $82.98 * * *$ & $88.59 * * *$ & $51.82 * * *$ \\
\hline Breusch-Pagan-Godfrey & $15.19 * * *$ & $69.57 * * *$ & $43.89 * * *$ & $25.40 * *$ \\
\hline
\end{tabular}

Note:

$* * *, * *$ and $*$ represent significance at the $1 \%, 5 \%$ and $10 \%$ levels respectively (1-tail for main variables; 2-tail for industry dummies) using White's (1980) heteroskedasticconsistent covariance matrix estimation to adjust for heteroskedasticity. 
the Breusch-Pagan-Godfrey statistics (reported at the foot of the tables) generally indicate significant heteroskedasticity. Consequently, all significance tests are reported using White's (1980) heteroskedastic-consistent covariance matrix estimation. Further, the Jarque-Bera test for normality of residuals (also in tables) indicates significant non-normality. ${ }^{23}$

\section{(iv) Analysis by Company Size}

Large companies are well-researched by the investment analyst community and there is some evidence that analysts adjust financial risk measures for operating leases for this group (Dresdner Kleinwort Benson, 1998). However, both mediumsized and particularly small listed companies receive less attention from analysts. Consequently, one argument put forward in the recognition versus disclosure debate is that disclosure is not an adequate substitute for recognition for smaller and medium sized companies. In view of this argument, it is important to identify whether the market makes a financial risk adjustment for operating leases across all sizes of company or whether the adjustment is restricted to large, well-researched companies.

Model 2 (Table 4) was re-estimated for three different size groupings based on total assets for the 1994 year-end. The cut-off points were chosen by reviewing a size-ranked list of companies and seeking (subjectively) to identify natural break-points. Homogeneity was evident in the groupings adopted when testing for heteroskedasticity in the regression modelling. The process yielded 24 large companies (assets $>£ 1,000 \mathrm{~m}$ ), 46 medium-sized companies $(£ 100 \mathrm{~m}<$ assets $<£ 1,000 \mathrm{~m})$ and 86 small companies (assets $<£ 100 \mathrm{~m})$.

The two regressions for the sub-samples of medium-sized and small companies gave similar sizes and signs for coefficient estimates to those obtained for the whole sample and both had good explanatory power (adj $R^{2}=43 \%$ and $55 \%$ respectively). The significance levels were also similar and were, for medium and small companies respectively: operating/asset risk $(1 \%, 5 \%)$, financial risk $(5 \%, 1 \%)$ and most importantly operating lease adjustment $(1 \%, 5 \%)$. Thus, the adjustment to financial risk for off-balance sheet operating leases does not appear to be confined 
to large, well-researched companies. The results for large companies were somewhat sensitive to a few highly influential data points within the small sample of 24 companies. The sign on the operating lease adjustment variable was consistently positive, but its size and significance were dependent on the specific companies in the regression data set. This may also partially reflect the relatively low use of leasing by large companies, which

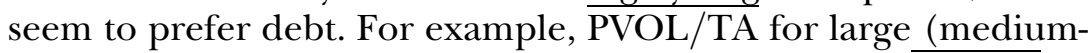
sized) companies was $12.6 \%(15.0 \%)$ compared with $\overline{D_{\text {rep }} / \mathrm{TA}}$ of $27.6 \%(18.5 \%)$ respectively.

In summary, UK investors/analysts do appear to recognise operating lease liabilities in their assessment of equity risk, a result that is consistent with the US but inconsistent with the Australian evidence. In the UK, there is little evidence to suggest that the rental-based factor method of estimating operating lease liability reflects actual behaviour more accurately than a process of constructive capitalisation. In the US, it is also not clear which method of operating lease assessment is more strongly associated with equity risk. Ely (1995a) found no difference whereas ILW found the factor method to have greater explanatory power. Further, the UK market recognises operating leases for small and medium-sized companies as well as for the large companies with high analyst interest.

\section{(v) ROA Adjustment for Operating Leases}

While the impact of the capitalisation of operating leases on equity risk is likely to be mainly through the adjustment to the financial risk measure, the main proxy used in this study for operating/asset risk $\left(\sigma_{\mathrm{ROA}}\right)$ is also affected as discussed in Sections 3(ii) and (v) above. Companies that would experience a fall in ROA if operating leased assets were capitalised $(\rho>1)$ would also experience a fall in the variability of ROA $\left(\sigma_{\mathrm{ROA}}\right)$, if this directional impact is stable over time. Of the 156 companies, 17 have no operating leases so $\rho=1,58$ have $\rho>1$ (denoted $H$ ) and 81 have $\rho<1$ (denoted $L$ ). Thus, for 58 companies, the impact on $\sigma_{\mathrm{ROA}}$ is expected to be negative and for 81 companies it is expected to be positive; lower operating/asset risk should be associated with lower equity risk and vice versa. The mean (median) values for $\rho$ for the $L$ and $H$ groups of companies are 
$0.930(0.976)$ and $1.370(1.020)$ respectively, suggesting that typically ROA (and therefore also $\sigma_{\mathrm{ROA}}$ ) would decrease (increase) by approximately $2 \%$, based on the median.

Table 6 reports the regression estimates for equation (7), which is model 2 with additional interactive dummy terms for expected ROA impacts. The inclusion of the interactive dummy variables has increased slightly the explanatory power, with adj $R^{2}$ increasing to $57 \%$ from $54 \%$ in model 2. The signs of $\beta_{1 L}, \beta_{1 H}$ (on $\sigma_{\mathrm{ROA}}$ itself) and $\beta_{3 L}$ and $\beta_{3 H}$ are as expected, but the signs for $\beta_{2 L}, \beta_{2 H}$, and the smaller size for $\beta_{3 L}$ than $\beta_{3 H}$, are contrary to expectation on the assumption that UK investors adjust the ROA ratio for operating leases in their assessment of equity risk. The expected signs of the $\sigma_{\mathrm{ROA}}$ interactive terms and the significance of $\beta_{1 H}$ provide some evidence to support the contention that investors adjust ROA for operating leases when assessing equity risk. However, overall the results provide only mixed evidence, consistent with the findings of Ely (1995a).

\section{SUMMARY AND CONCLUSIONS}

The aim of the present study is to contribute to the ongoing recognition versus disclosure debate by investigating the relationship between operating lease disclosures and equity risk assessments made by the capital market in the UK. The approach adopted is to conduct an indirect test using OLS regression analysis to determine whether there is an association between equity risk and an operating lease adjustment to financial risk. This test provides evidence as to whether investors/analysts view operating leases from a property rights perspective or from an ownership perspective. Two alternative operating lease evaluation methods are considered in order to establish which method, if either, appears to be employed by UK investors/ analysts. The first is a sophisticated present value method based upon a constructive capitalisation procedure; the second method is a simple factor method.

The empirical results provide evidence of a positive relationship between equity risk and the adjustment for operating lease liabilities. This result is robust to alternative proxies for operating/asset risk and for financial risk. Thus, UK 


\section{Table 6}

Investigation of the Impact of Operating Leases on the Assessment of Operating (Asset) Risk $\left(\sigma_{\mathrm{ROA}}\right)$ : OLS Regressions with Total Equity Risk $\left(\sigma_{S, 60,94}\right)$ as Dependent Variable

\begin{tabular}{|c|c|c|c|c|c|}
\hline Variable & Coefficient ${ }^{1}$ & $\begin{array}{l}\text { Expected } \\
\text { Sign }^{1}\end{array}$ & Coeff. & t-stat. & $\begin{array}{l}\text { 1-tail } \\
\text { p-value }\end{array}$ \\
\hline \multicolumn{6}{|c|}{ Operating (asset) risk } \\
\hline$\sigma_{\mathrm{ROA}}$ & $\beta_{1}$ & + & 1.139 & 2.39 & $0.0091 * * *$ \\
\hline$\sigma_{\mathrm{ROA}} \times L$ & $\beta_{1 L}$ & + & 0.631 & 1.04 & 0.1496 \\
\hline$\sigma_{\mathrm{ROA}} \times H$ & $\beta_{1 H}$ & - & -2.187 & -2.59 & $0.0054 * * *$ \\
\hline
\end{tabular}

Financial risk

$\begin{array}{lllrrr}\left(\overline{D_{\text {rep }} / \mathrm{TA}}\right) \times \sigma_{\mathrm{ROA}} & \beta_{2} & + & 4.627 & 1.16 & 0.1244 \\ \left(\overline{D_{\text {rep }} / \mathrm{TA}}\right) \times \sigma_{\mathrm{ROA}} \times L & \beta_{2 L} & + & -0.237 & -0.06 & 0.5232 \\ \left(\overline{D_{\text {rep }} / \mathrm{TA}}\right) \times \sigma_{\mathrm{ROA}} \times H & \beta_{2 H} & - & 10.282 & 1.98 & 0.9750\end{array}$

Operating lease adj

\begin{tabular}{|c|c|c|c|c|c|}
\hline $\mathrm{PVOL} / \mathrm{TA}) \times \sigma_{\mathrm{ROA}} \times L$ & $\beta_{3 L}$ & + & 1.070 & 2.13 & $0.0174 * *$ \\
\hline$\overline{\mathrm{PVOL} / \mathrm{TA}}) \times \sigma_{\mathrm{ROA}} \times H$ & $\beta_{3 H}$ & + & 2.052 & 4.98 & $0.0000 * * *$ \\
\hline constant & & & 0.255 & 19.92 & $0.0000 * * *$ \\
\hline$n$ & & & & 156 & \\
\hline Adj $R$ sq & & & & 0.570 & \\
\hline$F$ & & & & 26.67 & $0.00 * * *$ \\
\hline Jarque-Bera & & & & 44.20 & $0.00 * * *$ \\
\hline Breusch-Pagan-Godfrey & & & & 17.46 & $0.00 * * *$ \\
\hline
\end{tabular}

Notes:

$1 \quad L$ is a dummy variable $=1$ for companies with $\rho<1$, and 0 otherwise.

$H$ is a dummy variable $=1$ for companies with $\rho>1$, and 0 otherwise.

where $\rho=\mathrm{ROA}_{r e p} / \mathrm{ROA}_{a d j}$, assumed constant through time.

$\mathrm{ROA}_{\text {rep }}=$ reported ROA based on 1994 financial statements.

$\mathrm{ROA}_{a d j}=$ ROA for 1994 after adjustment for operating lease capitalisation .

Thus, if the market adjusts ROA for operating leases and as a result, a company's ROA decreases $(\rho>1)$, then the variability of ROA over time $\left(\sigma_{\mathrm{ROA}}\right)$ will also decrease and coefficients $\beta_{1 H}$ and $\beta_{2 H}$ should be negative (see text for further discussion of this and the expected signs of $\beta_{3 L}$ and $\beta_{3 H}$ ).

$2 * * *, * *$ and $*$ represent significance at the $1 \%, 5 \%$ and $10 \%$ levels respectively using White's (1980) heteroskedastic-consistent covariance matrix estimation to adjust for heteroskedasticity.

investors/analysts do appear to recognise operating lease liabilities in their assessment of equity risk, a result that is consistent with US findings but inconsistent with Australian evidence. In the UK, there is little evidence that the rental-based factor method reflects actual behaviour more accurately than the constructive capitalisation method. In the US, Ely (1995a) also 
found no difference between the methods of operating lease adjustment, but ILW (1993) found the factor method to have greater explanatory power.

If, for lessee companies, the risks associated with operating leases are equivalent to those associated with debt, then the coefficients on debt and the operating lease adjustment are expected to be equal. In fact, the coefficient on debt was statistically significantly higher than on the operating lease adjustment, suggesting that debt contributes more highly to the market's assessment of equity risk. Overall, these results indicate that investors/analysts view operating leases as property rights, taking them into account in their assessment of equity risk, and that the market considers the risks associated with operating leases to be lower than those associated with debt. This is consistent with previous UK empirical research, which found that companies' total lease obligations and non-leasing debt were substitutes rather than complements (Beattie et al., 2000). The market's assessment of lower operating lease risk is also consistent with Beattie et al.'s finding that companies act as if leasing and debt are imperfect substitutes, with the implication that company management perceive operating lease obligations as less risky. Given the usual retention of some residual value risk by lessors in operating lease contracts, this is not too surprising.

While the impact of the capitalisation of operating leases on equity risk is likely to be mainly through an adjustment to financial risk measures, a secondary adjustment to operating/ asset risk via the ROA ratio is also possible. This was investigated but mixed results were obtained.

The observation that the factor method of estimating operating lease liabilities is not favoured over constructive capitalisation may reflect increasing investor/analyst sophistication over time. The dangers of over-estimation of the operating lease liability using the factor method are perhaps now better known (Dresdner Kleinwort Benson, 1998).

The market's recognition of operating lease liabilities across different company size groupings is consistent with a measure of market efficiency. It tends to refute the argument that recognition of operating leases on companies' balance sheets is necessary to reduce imperfections in the small (and perhaps 
medium-sized) sectors of the listed company market. Although these sectors have lower levels of analyst interest and research, relevant operating lease information is being impounded in the market's assessment of equity risk in these sectors.

A major issue, which is outside the scope of the present research, is whether the market adjusts equity risk appropriately for the additional risk associated with unrecorded operating lease liabilities. In other words, while the evidence suggests that the market does incorporate operating leases in its equity risk assessments, is the size of the adjustment correct? This depends on two factors, the adequacy of the detail disclosed by way of footnote detail and the information processing ability of the market. One option for accounting standard setters would be to require more detailed footnote disclosure on operating leases. Some would argue that this would worsen the present situation of perceived 'information overload' in financial statements. The alternative of requiring recognition of operating lease liabilities (and assets) on balance sheet has the advantage of not depending on the information processing ability of investors. Company management has specific knowledge of the lease contracts and is best placed to measure related assets and liabilities. However, as the recent discussion paper (ASB, 1999) acknowledges, there are considerable difficulties involved in prescribing measurement rules that will be robust to the many different current (and future) contractual complexities.

The contribution of the present research is that it confirms that the UK market views operating leases from a 'property rights', rather than ownership, perspective. This seems to support the standard setters' search for an acceptable measurement basis on which these rights and obligations can be recognised 'on-balance sheet'.

\section{APPENDIX}

\section{Illustrative Calculation of PVOL: Constructive Capitalisation of Operating Leases for BOC Group Plc}

In the footnotes to the financial statements for the 1994 year end, BOC disclosed next year's operating lease commitments of 
$£ 18,700 \mathrm{k}$ for land and buildings, and $£ 10,600 \mathrm{k}$ for other assets, categorised according to date of expiration in the following way:

$\begin{array}{lcc}\text { Expiration Date } & \text { Land } \mathcal{E} \text { Buildings } & \text { Other Assets } \\ & £ 000 & £ 000 \\ \text { less than 1 year } & 2,100 & 1,800 \\ 1 \text { to } 5 \text { years } & 10,100 & 6,600 \\ \text { over 5 years } & \underline{6,500} & \underline{\underline{18,200}} \\ \text { Total } & \underline{\underline{18,700}} & \underline{\underline{10,600}}\end{array}$

These disclosures, along with the following assumptions of remaining lives, allow the operating lease liability as at year end 1994 (PVOL) to be calculated by discounting at an assumed interest rate of $10 \%$.

Expiration Date

\begin{tabular}{cc}
\multicolumn{2}{c}{ Remaining Life } \\
Land $\mathcal{E}$ Buildings & Other Assets \\
1 & 1 \\
3 & 3 \\
16 & 7
\end{tabular}

Years

Payment Amount Discount Factor

Liability

less than 1 year

1 to 5 years

over 5 years

Discoun

1

2,100

0.9091

$(£ 000)$

$1-3$

10,100

2.4869

1,909

$1-16$

6,500

7.8237

25,118

Total present value of land and buildings (PVOL) 50,854

Further details of the process, justification of the assumptions made, and sensitivity analysis can all be found in Beattie et al. (1998).

\section{NOTES}

1 A great deal of the debate centres on the trade-off between relevance and reliability, both of which are critical qualitative attributes of accounting information. Recognition criteria generally require that elements be capable of measurement with reasonable reliability. Moreover, some writers argue that the choice between recognition and disclosure signals management's knowledge about an item's reliability (Healy and Palepu, 
1993), and that disclosure is interpreted by users as being less reliable than recognition (Amir and Ziv, 1997, p. 65).

2 Another set of market-based studies examines the market reaction to a mandated change from disclosure to recognition (e.g., Espahbodi, Strock and Tehranian, 1991), the value-relevance of disclosures (e.g., Choi, Collins and Johnson, 1997), and the differential rate at which the market capitalises recognised liabilities compared to disclosed liabilities (Davis-Friday, Folami, Liu and Mittelstaedt, 1999).

3 Harper et al. (1987 and 1991), using US subjects, find that footnote disclosure of unfunded pension liabilities is not equivalent to balance sheet recognition. Wilkins and Zimmer (1983a and 1983b) and Wilkins (1984) find, using Singapore-based subjects, that, although share valuations made by investment analysts were unaffected by alternative reporting methods, this was not the case for predictions of company earnings, which may rely more heavily on accounting information compared to share valuations. Munter and Ratcliffe (1983) considered whether investment managers attach economic significance to alternative treatments of leases. They concluded that investors' decisions did reflect alternative operating lease accounting treatments, with capitalisation having an adverse effect. In their survey study of leases, pensions and post-retirement benefits, Gopalakrishnan and Parkash (1996) found that both borrowers and lenders are more likely to consider recognised obligations than disclosed obligations as debt-equivalent. Further, lenders consider disclosed obligations to be more like debt than borrowers do.

4 See Beattie, Edwards and Goodacre (1998, pp. 233-35) for a detailed description of the UK (and US) lease accounting regulations.

5 A direct market-based test of the equivalence of recognition versus disclosure is not possible in an ex ante setting, nor can the accuracy of operating lease evaluations and their impounding into share prices be assessed.

6 See Ely (1995a) and references therein for a discussion of the property rights/ownership debate.

7 A prior study of market risk assessment of operating lease disclosures in the US by Ely (1995a) uses a data set that ends in 1987. The magnitude of leasing has grown significantly since that date.

8 Arnold et al. (1984) found significant differences to exist between the security appraisal procedures performed by UK and US analysts. US analysts were found to consider financial results and make forecasts over a longer time scale. They were also found to undertake more fundamental analysis and to rate the profit and loss and balance sheet as more influential than UK analysts. More specifically, US analysts place more importance on cash flows and financial ratios, on which operating leases could have major impact.

9 A study by Anderson and Epstein (1996, p. 165) found varying degrees of self reliance by shareholders in different countries, with shareholders in the US being more self reliant than in Australia and New Zealand.

10 The research design did not permit the adjustments made in response to each of the nine forms to be assessed individually.

11 Narayanaswamy (1994) investigated the impact on equity risk of disclosed finance lease liabilities for large UK companies. He found that finance leases were positively associated with equity return volatility but that the market perceived finance leases to be less risky than debt. 
12 If the theoretical model is sufficiently strong, the coefficients $\beta_{0}$ and $\beta_{1}$ are expected to equal 0 and 1 respectively, and $\beta_{2}$ should equal $(1-t)$. However, there are several reasons why this might not occur empirically. First, the model makes the improbable assumption that the marginal tax rate is identical across firms. Second, accounting methods may cause $\sigma_{\text {ROA }}$ to be consistently higher or lower than an appropriate operating/asset risk measure. Third, debt comprises various liabilities which may not all have the same relationship with equity risk (Ely, 1995a). When using similar models, Bowman (1980a), Dhaliwal (1986) and Ely (1995a) all report empirical coefficients that do not match theory. Thus, detailed interpretation based on the size of coefficients is unlikely to be tenable.

13 Regressions were also performed with firm-specific risk as the dependent variable and almost identical resutls (not reported) were obtained.

14 To check the robustness of the results to the choice of a 60 month measure, two other proxies for equity risk were assessed, measured over 24 months and 36 months ending in 1994. The results obtained using these proxies were essentially similar and, therefore, are not reported.

15 The choice of seven years was a compromise between having sufficient data points to estimate the standard deviation and maintaining a reasonable overall sample size. The model was also derived using ten years to estimate $\sigma_{\mathrm{ROA}}$ with a reduced sample size of 125 companies and similar results (not reported here) were obtained. The use of average total assets as the denominator in ROA is to avoid the distortion that can occur when large amounts of new capital are raised during the year. Two further models based on opening assets (as Ely, 1995a used) yielded similar results.

16 Two other measures of the book value of debt, long term debt and net debt (i.e. total debt less cash equivalents) were also assessed and yielded similar results (not reported here).

17 Almost identical regression results were obtained using separate estimates of operating lease liabilities based on constructive capitalisation with interest rates of (i) $8 \%$ and (ii) $12 \%$, and (iii) shorter and (iv) longer lease life estimates for leases expiring beyond year 5 .

18 An alternative proxy was based on the next year's operating lease commitment reported in a footnote to the balance sheet. This excludes short-term rentals, contingent lease payments and lease contracts that have terminated during the year, but includes a full-year liability for new lease contracts. As almost identical results were obtained for this proxy, the results are not reported here.

19 Sample representativeness checks were carried out based on size (total assets, share capital plus reserves) and industry membership. These showed that the company size distribution and industry sector distribution of the sample approximated closely to that of the population. Twenty three different industrial sectors are represented in the sample with nine sectors having major representation (number of sample companies in brackets): building (19), electricals (16), retail (15), engineering (13), textiles (11), breweries (10), motors (9), leisure (9) and household goods (8).

20 Three outlier companies were identified during a preliminary set of diagnostic procedures and have been excluded from the analysis (Belsley et al., 1980). All three companies (Brent Walker, Castle Mill and Signet) suffered large losses for the accounting periods before and around 1994. As a result, they all underwent complete restructuring by selling off their loss making activities or by changing the focus of their business activities. Brent Walker's 
listing on the London Stock Exchange was eventually cancelled in 1997 when its lenders proceeded with liquidation. Castle Mill subsequently changed its name to BWL, and its activities from wholesale clothing distribution to aircraft services through the purchase of an unquoted company. The Signet Group's UK business was totally reorganised through major sell-offs before it returned to running profitably. Two further major outlier companies (International Business Communications, Upton and Southern) were identified during diagnostic testing of regression estimates; they consistently had very high influence (dffits and dfbetas) and distorted the underlying relationships of the rest of the sample. In particular, these two small companies had negative equity and extreme values for both $\sigma_{S}$ and $\sigma_{\mathrm{ROA}}$, thereby exerting a high degree of leverage on the results. On the basis of this information these companies were considered sufficiently atypical of the sample, and of the population it seeks to represent, to warrant exclusion from further analysis.

21 For large (TA $>£ 1,000 \mathrm{~m}$ ), medium-sized and small (TA $<£ 100 \mathrm{~m}$ ) companies in our sample the means for $\sigma_{\mathrm{ROA}}$ are respectively $0.025,0.041$ and 0.065 .

22 Alternative hypotheses are all uni-directional, so one-tail tests are reported throughout this study. This also facilitates compaison with Ely (1995a) who similarly reports one-tail critical $t$-values.

23 The theoretical structure proposed earlier is essentially linear in specification, so a log-transformation of the dependent variable $\left(\sigma_{S}\right)$, with its implied exponential relationship, is not supportable. However, for comparison with prior studies (Imhoff et al., 1993; and Gallery and Imhoff, 1998), a natural log transformation of the dependent variable, $\ln \left(\sigma_{S, 60,94}\right)$ was investigated. Using this specification, the residuals are normal and heteroskedasticity disappears. The signs and significance of the coefficients are essentially the same as those obtained without the log transformation.

\section{REFERENCES}

Amir, E. and A. Ziv (1997), 'Recognition, Disclosure or Delay: Timing the Adoption of SFAS No. 106', Journal of Accounting Research, Vol. 35, No. 1 (Spring), pp. 61-81.

Anderson, R.H. and M.J. Epstein (1996), The Usefulness of Corporate Annual Reports to Shareholders in Australia, New Zealand and the United States: An International Comparison (JAI Press, Greenwich, CT).

Arnold, J., P. Moizer and E. Noreen (1984), 'Investment Appraisal Methods of Financial Analysts: A Comparative Study of U.S. and U.K. Practices', International Journal of Accounting, Vol. 19, No. 2, pp. 1-18.

ASB (1999), Leases: Implementation of a New Approach, Discussion Paper (Accounting Standards Board, London).

ASC (1984), Accounting for Leases and Hire Purchase Contracts, Statement of Standard Accounting Practice No. 21 (Accounting Standards Committee, London).

Axelson, K.S. (1971), 'Needed: A Generally Accepted Method for Measuring Lease Commitments', Financial Executive (July), pp. 40-52.

Beattie, V.A., K. Edwards and A. Goodacre (1998), 'The Impact of Constructive Operating Lease Capitalisation on Key Accounting Ratios', Accounting and Business Research, Vol. 28, No. 4, pp. 233-54. 
Beattie, V.A., A. Goodacre and S. Thomson (2000), 'Operating Leases and the Assessment of Lease-debt Substitutability', Journal of Banking and Finance, Vol. 24, No. 3, pp. 427-70.

Beaver, W., P. Kettler and M. Scholes (1970), 'The Association Between Market Determined and Accounting Determined Risk Measures', The Accounting Review, Vol. 45, No. 4 (October), pp. 654-82.

Belsley, D.A., E. Kuh and R.E. Welsch (1980), Regression Diagnostics: Identifying Influential Data and Sources of Collinearity (John Wiley \& Sons, New York).

Bowman, R.G. (1979), 'The Theoretical Relationship between Systematic Risk and Financial Accounting Variables', Journal of Finance, Vol. 34, No. 3 (June), pp. 617-30.

(1980a), 'The Debt Equivalence of Leases: An Empirical Investigation', The Accounting Review, Vol. 55, No. 2 (April), pp. 237-53. (1980b), 'The Importance of a Market-Value Measurement of Debt in Assessing Leverage,' Journal of Accounting Research, Vol. 18, No. 1 (Spring), pp. 242-54.

Breton, G. and R.J. Taffler (1995), 'Creative Accounting and Investment Analyst Response', Accounting and Business Research, Vol. 25, No. 98, pp. 81-92.

Choi, B., D.W. Collins and W.B. Johnson (1997), 'Valuation Implications of Reliability Differences: The Case of Nonpension Postretirement Obligations', The Accounting Review, Vol. 72, No. 3 (July), pp. 351-83.

Davis-Friday, P.Y., L.B. Folami, C-S. Liu and H.F. Mittelstaedt (1999), 'The Value Relevance of Financial Statement Recognition vs. Disclosure: Evidence from SFAS 106', The Accounting Review, Vol. 74, No. 4 (October), pp. 40323.

Day, J.F.S. (1986), 'The Use of Annual Reports by UK Investment Analysts', Accounting and Business Research, Vol. 16, No. 64 (Autumn), pp. 295-307.

Dhaliwal, D.S. (1986), 'Measurement of Financial Leverage in the Presence of Unfunded Pension Obligations', The Accounting Review, Vol. 61, No. 4 (October), pp. 651-61.

Dresdner Kleinwort Benson (1998), Operating Leases: The Retail House of Cards (Dresdner Kleinwort Benson Research, London).

Edwards, K. (1997), The Impact of Constructive Operating Lease Capitalisation on Key Accounting Ratios, MSc Thesis (University of Stirling).

Ely, K.M. (1995a), 'Operating Lease Accounting and the Market's Assessment of Equity Risk', Journal of Accounting Research, Vol. 33, No. 2 (Autumn), pp. $397-415$.

(1995b), 'Cross-Sectional Differences in the Relation between the Accounting Return on Assets and Equity Risk', Journal of Accounting, Auditing and Finance, Vol. 10, No. 3 (Summer), pp. 437-58.

Espahbodi, H., E. Strock and H. Tehranian (1991), 'Impact on Equity Prices of Pronouncements Related to Non-Pension Post Retirement Benefits', Journal of Accounting and Economics, Vol. 14, No. 4 (December), pp. 323-46.

FASB (1984), Statement of Financial Accounting Standards No.5: Recognition and Measurement in Financial Statements of Business Enterprises (Financial Accounting Standards Board, Stamford, CT).

Finance and Leasing Association (1994), Annual Report 1994 (Finance and Leasing Association, London).

Gallery, G. and E.A. Imhoff (1998), 'Disclosure versus Recognition: Some Evidence from the Australian Capital Market Regarding Off-Balance Sheet Leasing', Paper presented at the University of Melbourne, Research Seminar Series. 
Gopalakrishnan, V. and M. Parkash (1996), 'The Debt-equivalency of Recognized vs. Disclosed Obligations: An Examination of Borrower and Lender Perceptions', Research in Accounting Regulation, Vol. 10, pp. 63-77.

Hamada, R.S. (1972), 'The Effect of the Firm's Capital Structure on the Systematic Risk of Common Stocks', Journal of Finance, Vol. 27, No. 2 (May), pp. $435-52$.

Harper, R.M., W.G. Mister and J.R. Strawser (1987), 'The Impact of New Pension Disclosure Rules on Perceptions of Debt', Journal of Accounting Research, Vol. 25, No. 2 (Autumn), pp. 327-30.

(1991), 'The Effect of Recognition Versus

Disclosure of Unfunded Postretirement Benefits on Lenders' Perceptions of Debt', Accounting Horizons, Vol. 5, No. 3 (September), pp. 50-56.

Healy, P.M. and K.G. Palepu (1993), ‘The Effect of Firm's Financial Disclosure Strategies on Stock Prices', Accounting Horizons, Vol. 7, No. 1 (March), pp. $1-11$.

Houlihan, W.A. and A.C. Sondhi (1984), 'De Facto Capitalization of Operating Leases: The Effect on Debt Capacity', Corporate Accounting, Vol. 2, No. 3, pp. 3-13.

Imhoff, E.A., R.C. Lipe and D.W. Wright (1991), 'Operating Leases: Impact of Constructive Capitalization', Accounting Horizons, Vol. 5, No. 1, pp. 51-63. (1993), 'The Effects of Recognition Versus Disclosure on Shareholder Risk and Executive Compensation', Journal of Accounting, Auditing and Finance, Vol. 8, No. 4 (Fall), pp. 335-68.

(1995), 'Is Footnote Disclosure an Adequate Alternative to Financial Statement Recognition?' Journal of Financial Statement Analysis, Vol. 1, No. 1 (Fall), pp. 70-81.

Johnson, L.T. (1992), 'Research on Disclosure', Accounting Horizons, Vol. 6, No 1 (March), pp. 101-3.

McGregor, W. (1996), Accounting for Leases: A New Approach (Financial Accounting Standards Board, Stamford, CT).

Modigliani, F. and M. Miller (1958), 'The Cost of Capital, Corporation Finance and the Theory of Investment', American Economic Review, Vol. 48 (June), pp. 261-97.

(1963), 'Corporate Income Taxes and the Cost of Capital: A Correction', American Economic Review, Vol. 53, No. 3 (June), pp. 433-43.

Munter, P. and T.A. Ratcliffe (1983), 'An Assessment of User Reactions to Lease Accounting Disclosure', Journal of Accounting, Auditing and Finance, Vol. 6, No. 2, pp. 108-14.

Narayanaswamy, R. (1994), 'The Debt Equivalence of Leases in the UK: An Empirical Investigation', British Accounting Review, Vol. 26, No.4 (December), pp. 337-51.

PricewaterhouseCoopers Leasing Team (1998), Tolley's Leasing in the UK (Tolley Publishing, Croydon).

Rajan, R.G. and L. Zingales (1995), 'What Do We Know About Capital Structure? Some Evidence from International Data', Journal of Finance, Vol. 50, No. 5 (December), pp. 1421-60.

Schipper, K. (1994), 'Academic Accounting Research and the Standard Setting Process'. Accounting Horizons, Vol. 8, No. 4 (December), pp. 61-73.

SHAZAM (1997), SHAZAM User's Reference Manual Version 8.0 (McGraw-Hill, New York).

White, H. (1980), 'A Heteroskedasticity-covariance Matrix Estimator and a Direct Test for Heteroskedasticity’, Econometrica, Vol. 48, pp. 817-38. 
Wilkins, T. (1984), 'A Behavioural Investigation of Alternative Methods of Financing Capital Acquisitions and Lease Capitalization', Accounting and Business Research, Vol. 14, No. 56 (Autumn), pp. 359-66. and I. Zimmer (1983a), 'The Effect of Leasing and Different Methods of Accounting for Leases on Credit Evaluations', The Accounting Review, Vol. 58, No. 4, pp. 749-64.

(1983b), 'The Effect of Alternative Methods of Accounting for Leases - An Experimental Study', Abacus, Vol. 19, No. 1, pp. 64-75. 